\title{
Giant cell arteritis complicated by acute pancreatitis: a case report Deepthi Renuka Seneviratne ${ }^{1}$, Susan P Mollan*1, Samer Elsherbiny ${ }^{1}$ and Theresa Worstmann²
}

\author{
Address: ${ }^{1}$ Birmingham and Midland Eye Centre, City Hospital, Dudley Road, Birmingham, B18 7QU, UK and ${ }^{2}$ Queen's Hospital, Belvedere Road, \\ Burton-upon-Trent, Staffordshire, DE13 ORB, UK \\ Email: Deepthi Renuka Seneviratne - deepthisen@hotmail.com; Susan P Mollan* - soozmollan@doctors.org.uk; \\ Samer Elsherbiny - samer.elsherbiny@swbh.nhs.uk; Theresa Worstmann - theresa.worstmann@burtonhospitals.nhs.uk \\ * Corresponding author
}

Published: 17 November 2008

Journal of Medical Case Reports 2008, 2:346

This article is available from: http://www.jmedicalcasereports.com/content/2/1/346

(C) 2008 Seneviratne et al; licensee BioMed Central Ltd.

This is an Open Access article distributed under the terms of the Creative Commons Attribution License (http://creativecommons.org/licenses/by/2.0), which permits unrestricted use, distribution, and reproduction in any medium, provided the original work is properly cited.
Received: 30 March 2008

Accepted: 17 November 2008

\begin{abstract}
Introduction: We describe a case of giant cell arteritis in a woman who was treated with highdose systemic corticosteroids and subsequently developed acute pancreatitis.

Case presentation: A 78-year-old Caucasian woman presented with four weeks of progressive headache and scalp tenderness. One day before ophthalmology assessment, she had experienced visual obscurations in both eyes. Her visual acuity was $6 / 9$ in both eyes, with a right afferent pupillary defect and right swollen optic nerve. She was diagnosed as having temporal arteritis and was urgently treated with high-dose pulsed intravenous and oral corticosteroids. Her previous diet-controlled diabetes needed insulin and oral hyperglycaemic therapy to control erratic blood sugars. On day 8 of treatment with steroids, she became unwell with epigastric pain and vomiting. She was diagnosed with acute pancreatitis and was treated conservatively.
\end{abstract}

Conclusion: Acute pancreatitis, a potentially life-threatening condition, is a rare but important side effect of systemic corticosteroids.

\section{Introduction}

Giant cell arteritis (GCA) remains an enigmatic but serious systemic disorder that can lead to total irreversible blindness if not diagnosed and treated swiftly. The recommended treatment is systemic steroids and the initial dose is large [1]. Unlike rheumatologists, ophthalmologists tend to use larger doses, 1.2 to $2 \mathrm{mg} / \mathrm{kg}$ per day of prednisolone [1] and this probably reflects the different disease characteristics seen by the two specialities.

The common systemic side effects of prednisolone, such as gastrointestinal disturbances, dyspepsia, weight gain, neuropsychiatric changes and osteoporosis, are well known. However, acute pancreatitis is less well known.
Only two cases of acute pancreatitis exist in the ophthalmic literature following high-dose methylprednisolone treatment for acute optic neuritis $[2,3]$. The authors believe that our case highlights the first reported complication following corticosteroid treatment for vision threatening GCA.

\section{Case presentation}

A 78-year-old Caucasian woman, previously fit and with diet-controlled diabetes, complained of weight loss, progressive malaise, jaw claudication and scalp tenderness for 1 month. One day before assessment, she had had transient complete loss of vision in her right eye and partial loss of vision in her left eye. Her visual acuity was $6 / 9$ in 
both eyes; colour vision, as tested with Ishihara pseudochromatic plates, was markedly reduced in the right eye $(06 / 17)$ and normal in the left (17/17). A right afferent pupillary defect was present and dilated fundal examination revealed a right swollen optic nerve. On examination, she had a right tender, nodular, non-pulsatile temporal artery. The erythrocyte sedimentation rate (ESR) was 74 $\mathrm{mm} /$ hour (normal for women $\geq 50$ years old: $\leq 30 \mathrm{~mm} /$ hour) and C-reactive protein (C-RP) was $>52 \mathrm{mg} /$ litre (normal C-RP $<5 \mathrm{mg} /$ litre).

She had emergency treatment with high-dose pulsed intravenous methylprednisolone $250 \mathrm{mg} \mathrm{BD}$ and oral prednisolone $80 \mathrm{mg}$ OD to prevent visual loss. She was also started on oral alendronic acid $70 \mathrm{mg}$ once weekly and oral ranitidine $150 \mathrm{mg} \mathrm{BD}$. Her symptoms resolved and her inflammatory markers improved over the next 3 days (ESR $60 \mathrm{~mm} /$ hour, C-RP $42 \mathrm{mg} /$ litre), intravenous steroids were stopped and she continued on $80 \mathrm{mg}$ of oral prednisolone OD. However, her glycaemic control worsened (blood glucose $22.8 \mathrm{mmol} /$ litre) and she was managed initially with oral hypoglycaemics (metformin 850 mg OD from day 2); glibenclamide $160 \mathrm{mg}$ BD was added by day 4 ; and subcutaneous insulin ( 24 units OM and 6 units nocte) at day 6 finally stabilised the hyperglycaemia (blood glucose $11.6 \mathrm{mmol} /$ litre). At day 8 she became unwell with epigastric pain and vomiting. An abdominal $\mathrm{X}$-ray excluded bowel perforation and clinical chemistry revealed normal liver function tests and an abnormally high serum amylase of $459 \mathrm{U} /$ litre (normal range 0 to 99 $\mathrm{U} /$ litre). She was managed conservatively with intravenous fluids and analgesia. Her serum amylase normalised over 48 hours and her symptoms resolved and she was discharged with resolving right disc oedema (ESR $14 \mathrm{~mm} /$ hour).

She has remained under care with regular blood monitoring and after 8 months is currently maintained on 12.5 mg of prednisolone OD. No symptoms of pancreatitis or GCA have returned. On examination, she has temporal pallor of the right optic nerve (Figure 1) and a normal left optic nerve (Figure 2).

\section{Discussion}

Bowel ischaemia or infarction secondary to involvement of the mesenteric arteries has been reported as a rare extracranial feature of GCA [4]. The blood supply to the pancreas is from the splenic, gastroduodenal and superior mesenteric arteries [5], however, it is unlikely that GCA is the cause in this patient. The pancreatitis started after 8 days of high-dose steroid treatment, there was no evidence of bowel perforation on abdominal X-ray and the pancreatitis settled with conservative treatment and has not reoccurred after 8 months of follow-up. Another possibility is that the pancreatitis could be secondary to dis-

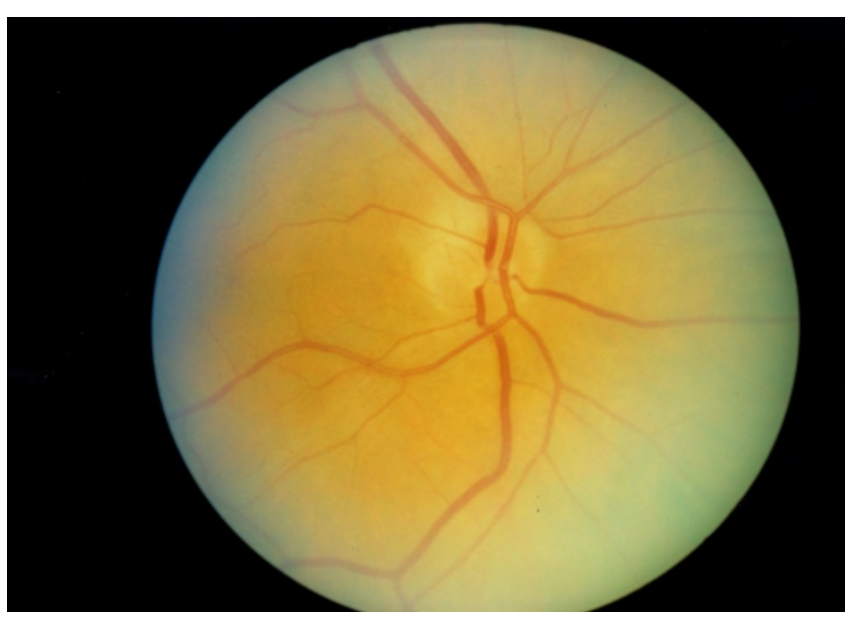

Figure I

Colour fundus image of the right eye.

seminated visceral giant cell arteritis. However, this is unlikely as Lie [6], who coined this entity, reported on four male cases none of whom had symptomatic temporal arteritis and all were diagnosed posthumously.

Acid-suppressing drugs, such as $\mathrm{H}_{2}$-receptor antagonists and proton pump inhibitors have also been implicated in causing drug-induced acute pancreatitis. A large, UKbased cohort study found no increased risk of acute pancreatitis following acid-suppressing drug administration [7].

Most cases of acute pancreatitis are mild and self-limiting, however, severe attacks can be fatal. Diagnosis is a combination of serum amylase levels three times the normal range (>330 U/litre) and typical clinical features including

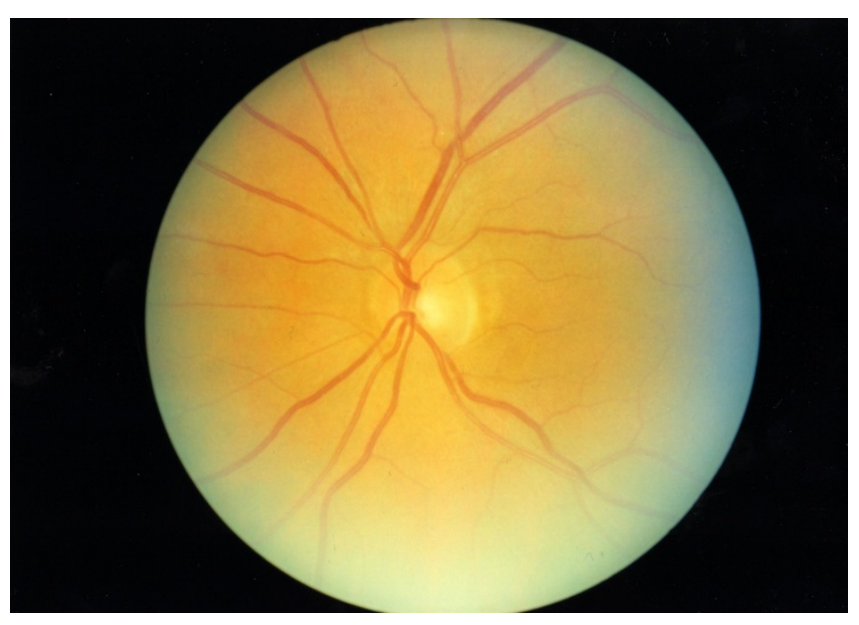

Figure 2

Colour fundus image of the left eye. 
epigastric pain radiating into the back, nausea and vomiting [8].

Only $1 \%$ of acute pancreatitis cases are secondary to systemic steroids, and these cases carry a relatively higher mortality rate $(66.7 \% ; \mathrm{n}=4 / 6)$ [6] compared to more common aetiological factors such as gallstones or chronic alcoholism $[8,9]$. The mechanism of corticosteroidinduced pancreatitis is complex and currently unknown.

\section{Conclusion}

It is highly probable that this case of acute pancreatitis was secondary to high-dose systemic steroids and we urge all physicians to be cognisant of this potentially life-threatening side effect.

\section{Abbreviations}

BD: twice a day; C-RP: C-reactive protein; ESR: erythrocyte sedimentation rate; GCA: giant cell arteritis; nocte: at night; OD: once daily; OM: once in the morning

\section{Consent}

Written informed consent was obtained from the patient for publication of this case report and any accompanying images. A copy of the written consent is available for review by the Editor-in-Chief of this journal.

\section{Competing interests}

The authors declare that they have no competing interests.

\section{Authors' contributions}

DS drafted the manuscript. SPM and SE critically reviewed the manuscript. TW supervised the patient management. All authors read and approved the final manuscript.

\section{References}

I. Ghanchi FD, Dutton GN: Current concepts in giant cell (temporal) arteritis. Surv Ophthalmol 1997, 42:99-I23.

2. Chrousos GA, Kattah JC, Beck RW, Cleary PA: Side effects of glucocorticoid treatment. Experience of the Optic Neuritis Treatment Trial. JAMA 1993, 269:2110-2112.

3. Julve Pardo R, Garcia-Escrig M, Catala Barcelo J, del Val JH, Fernandez Ponsati J: Acute pancreatitis as an effect of IV methylprednisolone in the treatment of optical neuritis. Neurologia 1998, 1 3:372-373.

4. Trimble MA, Weisz MA: Infarction of the sigmoid colon secondary to giant cell arteritis. Rheumatology 2002, 4 I : I08-I I0.

5. Bertelli E, Di Gregorio F, Mosca S, Batianini A: The arterial blood supply of the pancreas: a review. V. The dorsal pancreatic artery. An anatomic review and a radiologic study. Surg Radiol Anat 1998, 20:445-452.

6. Lie JT: Disseminated visceral giant cell arteritis: histopathologic description and differentiation from other granulomatous vasculitides. Am J Clin Pathol 1978, 69:299-305.

7. Eland IA, Huerta Alvarez C, Stricker BHCH, García Rodríguez LA: The risk of acute pancreatitis associated with acid-suppressing drugs. Br J Clin Pharmacol 2000, 49:473-478.

8. Beckingham IJ, Bornman PC: Acute pancreatitis. BMJ 200I, 322:595-598.

9. Trapnell JE, Duncan EHL: Patterns of incidence in acute pancreatitis. BMJ $1975,2: 179-183$.

\section{Publish with Biomed Central and every scientist can read your work free of charge}

"BioMed Central will be the most significant development for disseminating the results of biomedical research in our lifetime. "

Sir Paul Nurse, Cancer Research UK

Your research papers will be:

- available free of charge to the entire biomedical community

- peer reviewed and published immediately upon acceptance

- cited in PubMed and archived on PubMed Central

- yours - you keep the copyright 